\title{
Student's Perception of Common Rooms in Daarut Tauhid Tahfidz Islamic Boarding School,
}

\section{Bandung}

\author{
Rangga Firmansyah \\ Interior Design Study Program, School of \\ Creative Industries, \\ Telkom University, \\ Bandung, Indonesia \\ ranggafirmansyah@telkomuniversity.ac.id
}

Sumarni Ismail

Faculty of Design and Architecture,

Universiti Putra Malaysia (UPM),

Selangor, Malaysia

sumarni@upm.edu.my

\author{
Nangkula Utaberta \\ Research Fellow, Halal Products Research \\ Institute, \\ Universiti Putra Malaysia (UPM), \\ Selangor, Malaysia \\ nangkulautaberta@gmail.com \\ Golda Nensi Yuli \\ Department of Architecture, \\ Islamic University of Indonesia, \\ Yogyakarta, Indonesia \\ nensi@uii.ac.id
}

\author{
Nazlina Shaari \\ Faculty of Design and Architecture, \\ Universiti Putra Malaysia (UPM), \\ Selangor, Malaysia \\ nazlinashaari@upm.edu.my
}

\begin{abstract}
The Tahfidz Koran boarding school has a specialization curriculum and learning that the model is applied there that is different from the schools in general. Daarut Tauhid Islamic Boarding School is one of the Islamic boarding schools that implements an intensive program of memorizing the Koran for Approximately 1 year. This study uses a technique survey questionnaire on perceptions of students towards common room in boarding Tahfidz Koran Daarut Tawhid and found three related items include a pattern of activities, space, and time in the shared spaces, in addition to the privacy issues of students in need of additional facilities and the selection of the type of joint space and time of activities that support learning activities Tahfidz Koran.
\end{abstract}

Keywords: Tahfidz Koran, the Islamic boarding school, perception, Daarut Tauhid, the pattern of space-time-activity, students

\section{INTRODUCTION}

One Islamic educational institutions in Indonesia is Boarding School, he is the first and oldest education system in Indonesia [1], Many institutions of Islamic education in Indonesia today which promote and develop programs Tahfidz Koran, one of which is a boarding school Daarut Tawhid start Tahfidz Qur'an program in 2015. Tauhid Pesantren Daarut[2] is inseparable from the role of Ustadz Aa Gym that was pioneered in conjunction with teaching activities and entrepreneurs together KMIW (Kolompok Islamic Student Entrepreneur) in 1987, later formed the foundation Daarut Tauhid on September 4, 1990. In 1993 Daarut Tauhid Pesantren is growing by building a mosque assisted by the local community [3], The buildings of this region converge at the boarding school community environment, anyone can enter the boarding school environment Daarut Tauhid, including learning in it. Besides assimilation with the surrounding community, it is that allows the formation of the shared spaces in the boarding school environment and the learning process can also take place outside the classroom or in the learning environment by utilizing a variety of learning resources available.

\section{A. Problems in the area of communal room}

As mentioned in the introduction, the type of buildings in the area's boarding school that integrates with the surrounding communities. The phenomenon of shared space can only be encountered in a traditional boarding school type, Ruan-shared space can be accessed by anyone other than students both indoor and outdoor spaces such as in dormitories, pedestrian, hall, which are public[4], Islamic Boarding School in the development of environmental awareness, built environmental maintenance is not just aesthetics but rather the implementation of the enforcement purpose of Islamic values but Also pay attention to aspects of user needs and learning comfort[5],

Physical environment or space has an important influence on the process of rote learning of the Koran, because it needs to be considered sacred space conditions and strived room does not use either decor or colour images are striking, and protected from the atmosphere rowdy and noisy [6], The existence of a common room in the boarding school had an influence on the learning process of students who have different character and behaviour, so that the required standards of the facility development. This study tried to gather information and problems of the students in the room together while in boarding school Tahfidz Koran.

\section{RESEARCH METHOD}

This study was Carried out by employed some method of collecting and Analyzed data Following is the research methodology in collecting and Analyzed Data: Data Collecting Method using the site observation conducted during 4 months (March June 2019); to look for 1) a common room used by students in the learning activities Tahfidz Koran, 2) daily activity patterns are formed, 3) the type and time of the learning activities of students, survey; using questionnaires as the main instrument to get the perception of students toward a common room visits of two things, namely the aspects of function (related to the type of space, patterns of activity and the time it is formed in the area of shared space), the second is to find the factors that 
'study circles. In general, the activity halaqah [1], [18], [19] a learning activity tsaqafah Islamic boarding school with circular models made up of students and clerics to study a particular book.

Based on observations and interviews found there are four patterns of activity associated with learning students Tahfidz Koran;

1. Deposit rote; Technically, students deposit is generally 1 to 1 muhafizh / ah. However, there are some muhafizh / ah already mutqin 30 chapters can listen to 2-3 students at a time. Pupils who are ready to be directly approached recitation muhafizh / ah to deposit rote. If there are no students who deposit rote, muhafizh / ah usually memorize / muroja'ah own because usually he is also obliged to deposit rote outside halaqoh hours. Some there is quite a strict boarding school where memorizing activities carried out while waiting for their turn order deposit in the group, namely to sit in a first row in front muhafizh / ah. This usually applies to the boarding school whose program is intensive and install special achievement targets.

2. Fixing Reading (Tahsin); For those students who have not been a good reading required in talaqqi before memorization. Muhafizh / ah usually precede talaqqi before receiving payment from other students or designate one mushrifs / ah or other students who have good reading and rote to guide talaqqi. Usually on the first day, there was 1 session halaqoh used specifically for the learning tahsin. Some ponpes give you a choice in this session, for students who have good reading tahsin compulsory classes, while already well may choose to continue memorizing or join a class remain tahsin.

3. Exam; These students memorizing evaluation activities can be conducted once the weekly or monthly. Primarily carried 1 student with a rotating pattern $1 \mathrm{muhafizh} / \mathrm{ah}$ in one room. The shape of the test by reading rote obtained within 1 week/month, continued paragraph, guess the location of the paragraph, and/or guess the letter (depending on the policy ponpes). Other students who waited outside the room, repeating rote.

4. Tasmi '; Tasmi 'is done when there are students who have reached the rote 1 juz or more, or at the end of the program. Technically, all students gathered circular or air-rows. Pupils who recited from memory sitting in front facing the other students. The others listen and correct. In intensive programs that are usually tasmi 'held simultaneously in 1 or 2 days. Pupils will be divided into several groups. Each 1 group are supervised by one muhafizh / ah. Each group was placed in several spots / different elbow room, where if still in one area means to be far apart. In one such group is the students take turns each read, listen to, and correcting the entire recitation that achieved during the program.

User's perceptions were examined based on the following criteria:

\section{A. Activity patterns}

Based on interviews in the privacy aspects of the activities of the students following the learning program, school tahfidz DT, the first was rote activities, and the second is the deposit rote activities, two activities at the boarding school environment tahfidz DT known as activity 
Tahfidz Koran is the most important thing to note, though each of the students will seek its own way to be able to focus on when halaqoh. Regarding the privacy of students there are two types of privacy of the students; 1) The types of students are usually in crowded places (note: crowded with people who memorize well), 2) the type of students who ultimately find the angle or another quiet area, away from the noise of other people who memorize as easily distracted.

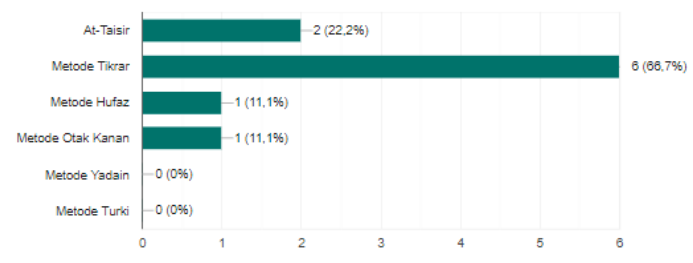

Fig. 1. Methods students in memorizing the Quran

Based on the results of questionnaires around $86 \%$ of students choose the method tikrar in memorizing the Quran, tikrar method is one method of memorization by way of reading or reciting al-Quran verses until completely attached and memorized. Method of tikrar also called Wahdah method, namely memorizing one by one of the verses that want to be memorized.

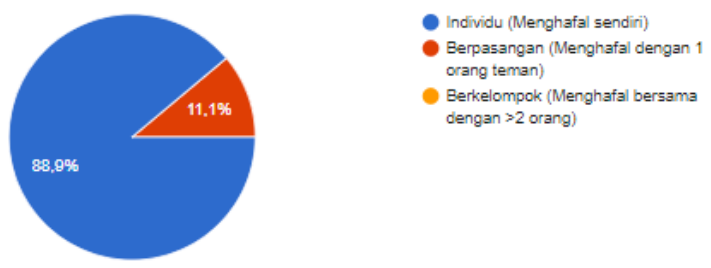

Fig. 2. Privacy of Students in Memorizing The Quran

Based on the results of questionnaires relating to the privacy of students in the recitation of the Koran activities about $88.9 \%$ feel comfortable doing it alone, and no respondents chose the type of memorizing in groups. Pupils need a special room to memorize the calm atmosphere and facilitated the table to put Manuscripts. In addition, the students prefer studying Lesehan position without using the chair in conducting rote.

\section{B. Pattern space}

Based on the results of questionnaires the students like the type of room is open and spacious, and most choose to do a rote activity outside the room than in the room.

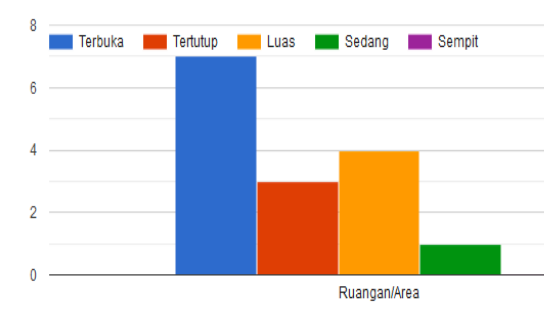

Fig. 3. The Type of Room in The Rote Activity
Pupils assumed that the shared spaces in the boarding school environment to facilitate them to meet each other and perform the learning activities Tahfidz the Quran together, around $44 \%$ said that the hall is a common room that can accommodate all learning activities Tahfidz al- Quran.

What is interesting is the shared space area is found in the boarding school Daarut Tauhid consisting of; 1) Hall, 2) Mosque, 3) Padepokan, the third area is the place that made by the students in conducting recitation of the Koran. Based on the results of questionnaires and interview of things that affect students in performing rote activities, associated with the room; students prefer open spaces with natural lighting \& airing. While the factors that are considered disturbing was the noise of people talking. The need for a dedicated space for the activities of memorization of the Koran with model 1 cubicle 1 students is more likely to get students more privacy in the conduct of individual recitation.

\section{C. pattern time}

The pattern of the selected time the students in conducting activities Tahfidz learning al-Quran in the form of daily activities, monthly, and yearly. Daily rote activities usually carried out in four-time, 1) after Fajr until before noon, 2) after the noontime until asr, 3) after Asar prayers until the time for maghrib, and last after evening prayers. In the monthly activity is usually filled with the evaluation of students through an annual exam consists of memorizing and learning activities tahfidz result of al-Quran which tasmi activities (when there are students who have reached the rote 1 juz or more, or at the end of the program), Pupils are able to concentrate around 45-60 minutes to perform a rote activity with results of questionnaires $88.9 \%$ said it is influenced by the condition of the room where they memorize, and $77 \%$ respondent stated the privacy they get in this area is optimal, even if students want additional facilities to support in the form of furniture for students rote activities.

\section{CONCLUSION}

There are three things which become the main finding in this study, the first is the 5 main activities in instructional programs Tahfidz al-Quran: 1) Memorize, 2) deposit rote, 3) Improve reading, 4) Examination memorization 5) tasmi. Both are pattern common room in the boarding schools that serve as the implementation of learning activities Tahfidz alQuran, consisting of 1) hall, 2) Mosques \& 3) hermitage. Recently, three students time pattern consisting of daily activity patterns, monthly, and yearly found in the study, 4 patterns of time spent by the students in conducting recitation of the al-Quran. Factors privacy and preferences towards patterns of activity,

\section{REFERENCES}

[1] O. Herman, "Al-ta'dib Journal Vol. 6 No. 2 July to December BOARDING SCHOOL HISTORY IN INDONESIA, "vol. 6, no. 2, pp. 145-158, 2013.

[2] WP Community, "Daarut Tauhid Pesantren," 2004.

[3] A. Rosidi, "Students Motivation In Memorizing the Qur'an," Research, Pp. 67-101, 2014.

[4] NG Yuli, Haningsih S., and R. Adikrishna, "The Common Room Design of Islamic Boarding School: A Preliminary Research in Yogyakarta Islamic Boarding School," Int. J. Eng. Technol., Vol. 11, 
2018.

[13] Prawindar Wulan Ayu Devi and Ismanto, "al-quran Tahfidz extracurricular learning in madrasah aliyah," 1 st Educ. Lang. Int. Conf. Proc. Cent. Int. Lang. Dev. Unissula, Pp. 236-246, 2012.

[14] S. Anwar, "Implementation of Tahfidzul Qur 'an Education At Elementary School-Aged Children At Pesantren Nurul Iman Tasikmalaya," EDUCATION J. penelit. Educators. Religion and Religious, Vol. 15, no. 2, pp. 263-282, 2017.

[15] P. Brown, M. and Long, "Trends in Learning Space Design," Oblinger, D. Learn. spaces, No. May, pp. 9.1-9.11 2006.

[16] B. Bligh and C. Crook, Learning spaces, 2017.

[17] T. Byers, W. IMMS, and E. Hartnell-Young, "Making the Case for Space: The Effect of Learning Spaces on Teaching and Learning," Curric. Teach., Vol. 29, no. 1, pp. 5-19, 2014.

[18] J. MT and S. Pamekasan, "BOARDING EDUCATION DEVELOPMENTS IN INDONESIA Mohammad Hasan Preliminary Studies of schools have done a lot of experts, with a variety of perspectives - such as socio-economic approach, political and economic ethics and behavior that are AGR.

[19] HP Daulay and T. Tobroni, "Islamic Education In Indonesia: A Historical Analysis Of Development And Dynamics," $\quad B r . \quad J$. Educ., Vol. 5, no. 13, pp. 109-126, 2017.

Arabic. Islam. Stud., Vol. 14, no. May 2010, pp. 47-62, 2014.
[12] MN Asadullah and Maliki, "Madrasah for private school for girls and boys? The determinants of school type of choice in rural and urban Indonesia," Int. J. Educ. Dev., Vol. 62, no. March, pp. 96-111, 